\title{
Effects of degraded lands restoration on soils physicochemical properties and adaptability of planted woody species in southwestern Niger
}

\author{
Noma Adamou Salifou ${ }^{1}$, Lahcen Daoudi ${ }^{2}$, and Amadou Abdourhamane Toure ${ }^{3}$ \\ ${ }^{1}$ Cadi Ayyad University \\ ${ }^{2}$ Cadi Ayyad University Faculty of Science and Technology Gueliz \\ ${ }^{3}$ Abdou Moumouni University Faculty of Science and Technology
}

September 25, 2021

\begin{abstract}
In the Sahel, exacerbated soils degradation is an ecological indicator of ecosystem vulnerability. This study examines the effects of restoration of degraded lands on soils physicochemical properties and adaptability of planted woody species over a period of 4-6 years. It is based on: 1) Physicochemical analyses of soils (granulometry, calcimetry, and organic matter) carried out on 102 samples taken in the upper 10 centimeters of the soil profile of the rehabilitated and control sites, 2) measures carried out for the dimensioning of anti-erosion structures, 3) dendrometric measurements on woody species planting in 20 plots each with a rectangular shape $60 \mathrm{~m} \times 30 \mathrm{~m}$ as well as characterization of the structure of their root systems. Physicochemical analyses show an improvement in soil quality and structure thanks to the erosion control measures. The degradation of anti-erosion structures, inferred from the rate of siltation of micro-basins, the subsidence of the bulges, the formation, and extension of the breaches, is strongly influenced by the topography, precipitation, and sandy texture of the soils. The restoration activities have led to the reconstitution of vegetation cover on degraded soils. Based on dendrometric characteristics, height class structure, and root systems architecture, significant differences were observed between woody species planted in anti-erosive structures. Eucalyptus camaldulensis groups of with a tracer root system and high density, have the highest structural parameters resulting from the adaptation of this species on Sahelian degraded lands.
\end{abstract}

\section{Hosted file}

Manuscript.docx available at https://authorea.com/users/436817/articles/538874-effectsof-degraded-lands-restoration-on-soils-physicochemical-properties-and-adaptability-ofplanted-woody-species-in-southwestern-niger

\section{Hosted file}

Tables.docx available at https://authorea.com/users/436817/articles/538874-effects-ofdegraded-lands-restoration-on-soils-physicochemical-properties-and-adaptability-ofplanted-woody-species-in-southwestern-niger

\section{Hosted file}

Figures.docx available at https://authorea.com/users/436817/articles/538874-effects-ofdegraded-lands-restoration-on-soils-physicochemical-properties-and-adaptability-ofplanted-woody-species-in-southwestern-niger 